УДК $82+398$. .

ББК 63.52I $(=62)+$

$82.3(=632)$

\section{ОГОНЬ, ПОТОП И ВОЙНА \\ С ВОСТОКА: КУЛЬТУРНЫЙ ТРАНСФЕР \\ В СОВРЕМЕННЫХ ЭСХАТОЛОГИЧЕСКИХ ПРЕДСТАВЛЕНИЯХ НА АЛТАЕ}

(C) 2018 г. Д.Ю. Доронин

Научно-исследовательская лаборатория теоретической фольклористики Школь актуальных гуманитарных исследований Института общественных наук Российской академии народного хозяйства и государственной службы при Президенте Российской Федерации, Москва, Россия Дата поступления статьи: 26 января 2018 г. Дата публикации: 25 сентября 2018 г.

DOI: $10.22455 / 2500-4247-2018-3-3-278-303$

Статья выполнена при поддержке гранта РГНФ, проект № I8-о9-оо744 «Современные сакральные практики освоения социальных ландшафтов на южном Алтае»

Аннотация: Проблематика культурного трансфера раскрывается в статье через описание буддийских центральноазиатских влияний и заимствований в эсхатологии и, шире, мифологии алтайцев. В частности, буддийское учение о кальпах сопоставляется с алтайскими представлениями об эсхатологических стихиях айгулах. Анализируется специфика алтайских эсхатологических представлений об огненной катастрофе и водах потопа, выходящих в конце времен из-под земли. С другой стороны, культурный трансфер исследуется на примере фольклорных текстов, демонстрирующих мифологизацию алтайцами других государств и народов (прежде всего, Китая и России) в фольклорных мотивах эсхатологической войны и иноземного нашествия. Представления о последней войне строятся на мессианских ожиданиях грядущего хана и на основании исторической памяти о потрясениях прошлого.

Ключевые слова: Республика Алтай, Алтай, алтайцы, эсхатология, бурханизм, шаманизм, Белая вера, алтайская эсхатология.

Информация об авторе: Дмитрий Юрьевич Доронин - научный сотрудник, Научно-исследовательская лаборатория теоретической фольклористики Школы актуальных гуманитарных исследований Института общественных наук Российской академии народного хозяйства и государственной службы при Президенте Российской Федерации, пр. Вернадского, 82, корп. 9, II957I г. Москва, Россия.

E-mail: demetra2@mail.ru

Для цитирования: Доронин Д.Ю. Огонь, потоп и война с Востока: культурный трансфер в современных эсхатологических представлениях на Алтае // Studia Litterarum. 20I8. T. 3, № 3. С. 278-303. DOI: I0.22455/2500-4247-2018-3-3-278-303 


\title{
FIRE, FLOOD AND WAR FROM THE EAST: CULTURAL TRANSFER IN ALTAIC MODERN ESCHATOLOGY
}

This is an open access article distributed under the Creative Commons Attribution 4.0 International (CC BY 4.0)

\author{
(C) 20I8. D.Y. Doronin \\ Research Laboratory of theoretical folklore studies, \\ School of advanced studies in humanities, School \\ of Public Policy, The Russian Presidential Academy \\ of National Economy and Public Administration, \\ Moscow, Russia \\ Received: January 26, 2018 \\ Date of publication: September 25, 2018
}

Acknowledgements: The article was supported by the grant of the Russian State Fund for the Humanities, project no I8-09-00744 "Modern Sacred Practices in the Development of the Social Landscapes in the Southern Altai."

Abstract: The article examines modern Altai eschatology from the standpoint of cultural transfer. For this purpose, it gives an overview of sources of Altai eschatology, including the main versions (subtradition) of Altai eschatology as well as its oral and folklore genres. It shows that Altai eschatology, especially its Burkhanism version, has not only circular but also axial, linear, or "historical" sense of time. The problem of cultural transfer is revealed through a description of obvious Buddhist Central Asian influences and borrowings in the eschatology and, more broadly, in the mythology of the Altaians. In particular, the Buddhist doctrine of the kalpas is compared with the Altaic notions of eschatological elements of the aiguls. Borrowings from Mongolian and Buddhist eschatology and mythology receive detailed examination. The essay examines the specificity of Altaic eschatological ideas about the fiery disaster and the flood waters emerging at the end of time from under the earth. Finally, the essay explores folklore texts that demonstrate the mythologization of other states and peoples (primarily China and Russia) by Altaians in the folklore motifs of the eschatological war and foreign invasion. Mythological ideas about the last war between eschatological peoples are built on the messianic expectations of the coming Khan and on the memory of the historical upheavals of the past.

Keywords: Altai Republic, Altai, Altaians, eschatology, Burkhanism, shamanism, White faith, Altai eschatology.

Information about authore: Dmitrii Y. Doronin, Research Fellow, Research Laboratory of Theoretical Folklore Studies, School of Advanced Studies in Humanities, School of Public Policy, The Russian Presidential Academy of National Economy and Public Administration, Vernadsky prospect, 82, building. 9, II957I Moscow, Russia.

E-mail: demetra2@mail.ru

For citation: Doronin D.Y. Fire, Flood and War from the East: Cultural Transfer in Altaic Modern Eschatology. Studia Litterarum, 20I8, vol. 3, no 3, pp. 278-303. (In Russ.) DOI: IO.22455/2500-4247-20I8-3-3-278-303 


\section{Алтайская эсхатология: жанры и субтрадиции}

Слабая изученность алтайской эсхатологии ${ }^{\mathrm{I}}$ побудила автора обратиться к данной теме. В настоящее время известны только две небольшие работы, специально посвященные этой теме [24;37], но и они сосредоточены на весьма частных вопросах (лишь на одном из эсхатологических жанров в одном случае и на бурханистской версии алтайской эсхатологии в другом) и поэтому не могут считаться обобщающими. Еще две недавних публикации посвящены современным эсхатологическим ожиданиям на Алтае [I4; I5]. Такое положение является частью более крупной проблемы - слабой изученности тюркской эсхатологии в целом, например, эсхатологические представления не упомянуты в энциклопедической статье «Тюркоязычных народов мифология» [4].

Не лучше обстоит дело с публикацией текстов: за полтора столетия в научный оборот было введено лишь девять алтайских эсхатологических текстов. [I, с. 342-345; 22, с. I34-I39; 24, с. 44; 28, с. I67-I70]. Как пишет исследователь несказочной прозы алтайцев и автор одной из двух статей по алтайской эсхатологии Н.Р. Ойноткинова, «у алтайцев зафиксировано 9 текстов о предстоящем конце мира. К сожалению, в настоящее время этот жанр угасает...» [24, с. 44]. Данное суждение необходимо пояснить:

\footnotetext{
I Эсхатологических представлений неисламизированных аборигенных тюркских народов Республики Алтай, т. е. в данной статье в первую очередь собственно алтайцев (алтай кижи) и теленгитов и в меньшей степени народов из группы так называемых «северных алтайцев»тубаларов, кумандинцев и челканцев. В некоторых случаях будут использованы материалы из мифологии телеутов, относимых ранее к группе «южных алтайцев» (наряду с теленгитами и алтай кижи).
} 
- во-первых, эсхатологическая традиция на Алтае, на мой взгляд, не угасает, a, наоборот, даже переживает некоторый ренессанс, яркий пример беседы-проповеди представителей каракольской группы $A \kappa J a r$ - 'Белой веры' (aлm.) и визионерские тексты автописьма, называемые алтайцами Алтай Кудайдын бичиктери - 'письма Алтай Кудая' (алт.) эсхатологической тематики, полученные писцами-бичикчилер в состоянии измененного состояния сознания и записанные ими в тетради;

- во-вторых, Н.Р. Ойноткинова имела в виду только опубликованные тексты;

- в-третьих, назвав статью «Эсхатологические мифы алтайцев», она рассмотрела эсхатологические тексты только одного жанра - так называемые тексты-пророчества [25, с. 25], в то время как жанров алтайских текстов, касающихся эсхатологической тематики, больше.

Здесь логично обратиться к рассмотрению других эсхатологических жанров алтайского фольклора и соответствующих им эсхатологических субтрадиций мифоритуальных систем тюрков Алтая. Тексты эсхатологического содержания, по уже устоявшейся научной традиции, алтайские фольклористы относят к крупной жанровой группе несказочного фольклора кеп-куучындар - ‘старинные рассказы’ (алm.) [25, с. г9]. При более пристальном рассмотрении можно убедиться, что тексты с эсхатологическими мотивами представлены в следующих жанрах:

I. Стихотворные силлабические тексты-пророчества, чаще всего приписываемые легендарным / историческим провидцам; по большей части это перечни примет / знаков эсхатологической эпохи.

2. Прозаические эсхатологические рассказы.

3. Мессианско-эсхатологические тексты бурханистской традиции.

4. Тексты визионеров [(бичикчи - 'писцов' (aлm.), камов - 'шаманов’ (aлm.)] с эсхатологическими мотивами. Например, так называемые «диктовки»² ак јану улус - 'сторонников Белой веры’ (aлm.), переведенные в машинописную и печатную форму (послания, листовки, газеты). Сюда же относятся дидактические и эсхатологические тексты современных шаманов и других ритуально-магических специалистов - неме билер улус - 'нечто

2 «Диктовки» - русскоязычное название подобных визионерских текстов, употребляемое самими алтайцами, которые верят, что духи или божество Алтай Кудай диктуют эти тексты писцам-бичикчилер как свои послания людям. 
знающих людей’ (aлm.), публикуемые ими в алтайских СМИ или даже в публикуемых ими книгах.

Среди алтайских речевых эсхатологических жанров можно указать: белге - 'угадывание по приметам и ситуациям' (короткие рассказы-предсказания, сообщаемые по какому-то случаю, например, когда рассказчик замечает растущий на горе молодой березовый лес) и табыш - ‘слух' (aлm.), короткие транслируемые сообщения этого речевого жанра также зачастую эсхатологически окрашены. Следует указать и на более долгие и пространные, иногда ритуализованные «вечерние беседы у огня», как томырыир / momuрuир / moмып (в смысле 'рассуждения, философствования'), в том числе на эсхатологическую тему, в айыле на таежной стоянке или в селе.

Вероятно, было бы большой ошибкой рассматривать современные алтайские эсхатологические представления вне определенного историко-культурного контекста. В настоящее время для Республики Алтай характерна сложная этноконфессиональная ситуация [І3, с. 29], что стало следствием бурного «национально-культурного возрождения» I990-х гг. [35, c. 30-42]. Сейчас одновременно сосуществуют и конкурируют друг с другом несколько «проектов идентичности», представлений об «алтайскости» и будущем алтайского народа:

- различные варианты шаманизма и (нео)шаманизма,

- различные варианты Ак Јан (Белой веры), известной русскоязычным исследователям с г904 г. как алтайский бурханизм,

- буддизм, в основном школы Гелугпа, но есть и проекты «алтайского буддизма»,

- «алтайский протестантизм», в основном церкви евангелического и харизматического толка, для которых (в отличие, например, от адвентистов Республики Алтай) «алтайскость», алтайское этнокультурное наследие (язык, обычаи и даже обряды, мифологические и эсхатологические мотивы) представляют большую ценность. С их точки зрения, Бог говорит алтайцам через алтайское, а сохранение и преумножение «алтайскости», алтайского народа - одно из важнейших последствий Его благословления,

- алтайское православие, в меньшей степени, чем протестантизм, окрашенное в «алтайские тона».

Каждое из этих конфессиональных направлений предлагает свои представления о будущем (в том числе катастрофические, эсхатологические 
и мессианские) и/или толкует по-своему традиционные алтайские эсхатологические мотивы. (Квази)исторические и мессианские представления об Ойроте также переосмысляются по-своему: например, как приход Майтреи, возвращение буддийской веры на Алтай, как приход сильного алтайского правителя, ведущего к возрождению народа или как второе пришествие Иисуса Христа. Таким образом, алтайская эсхатологическая традиция неоднородна, можно выявить несколько субтрадиций:

- бурханистскую (мессиански-эсхатологическую),

- шаманистскую,

- эсхатологические представления алтайских буддистов,

- эсхатологические представления алтайских протестантов-харизматов.

Большинство текстов эсхатологической тематики этих алтайских субтрадиций:

- либо описывают катастрофу прошлого, чаще всего потоп (такие тексты правильнее отнести в особую группу катастрофических),

- либо сообщают о знаках/приметах последнего века,

- либо, пророчествуя, описывают эсхатологические события (войны, катастрофы, порча мира, эпоха сомнительного благоденствия),

- либо сообщают о грядущем обещанном возвращении легендарного правителя и его деяниях, чаще всего возвышающих народ (группа мессианско-эсхатологических текстов).

Несколько слов необходимо сказать об историчности и моделях времени в алтайской эсхатологии. Бурханистская субтрадиция в наибольшей степени связана с легендарной историей и (квази)историей алтайцев. Именно поэтому для этой (мессианской) эсхатологии более всего характерно не кольцевое, а осевое, линейное, «историческое» ощущение времени. Поэтому было бы ошибкой вслед за некоторыми исследователями [I8; 25, c. 25-26] приписывать всей тюркской эсхатологии кольцевую модель времени. Элемент цикличности можно увидеть и в бурханистских текстах (мотив возвращения правителя), однако именно эти тексты конца джунгарского (ойротского) владычества³ над народами Алтая (XVIII в.) исследователи

3 Джунгарское ханство - государство западных монголов (ойратов) в XVI-XVIII вв. на территории, которая сейчас относится к Казахстану, Киргизии, Китаю, России и Монголии. Занимало земли от Тибета и Китая на юге до Сибири на севере, от Урала, Хивинского и Бухарского ханств на западе до Халха-Монголии на востоке. Перестало существовать после третьей ойратско-маньчжурской войны (I755-I759), междоусобицы и геноцида ойратов со 
чаще всего соотносят с реактуализацией в мифологии алтайских тюрков модели линейного, (квази)исторического времени [І8, с. 56]. Другие исследователи, например Л.И. Шерстова, связывают возникновение линейного, исторического времени с еще более поздней эпохой - с бурханистскими массовыми молениями алтайцев в I904 г. в урочище Тӧрӧн ${ }^{4}$. В концепции автора возникновение новой темпоральности связано с формированием нового (алтайского) этноса [37, с. I85]. На мой взгляд, исследователь, опираясь на фольклор бурханистов, конструирует свою собственную «мифологию времени» у алтайцев, причастную рождению их нового этноса.

Общую схему [7, с. I23] алтайской эсхатологии можно представить в виде последовательности тем (обобщающих, группирующих несколько близких мотивов)5: [г. Знамения и вестники эсхатологической эпохи] + [2. Эсхатологическая эпоха: 2.I. чудесный мир «технической эсхатологии» + 2.2. испорченный / перевернутый мир] + [3. Эсхатологическая война] + [4. Эсхатологическая катастрофа: айгуль, потоп, огненная катастрофа] + [5. Возвращающийся / грядущий правитель и новый мир].

Многие мотивы алтайской эсхатологии, по всей видимости, интернациональны: например, последняя война между народами, измельчание людей, утрата ценности золота (голодный человек не может выменять даже самую малость еды за большой самородок золота) или мотивы технической эсхатологии (железные быки и железные птицы, небо в паутине). Когда и откуда эти мотивы были заимствованы в алтайскую традицию или же они настолько давно транслируются на алтайском, что могут уже считаться частью местной эсхатологической традиции, - на все эти вопросы весьма сложно ответить. Но, на мой взгляд, предположение Н.Р. Ойноткиновой о том, что эсхатологические повествования появились в фольклоре алтай-

стороны Китая. Тюркские народы юга Алтая входили в состав ханства и вспоминают эту эпоху как свой «золотой век».

4 Моления сторонников Ак Јан (Белой веры) начала XX в., движения, для которого были характерны религиозно-националистические настроения (например, отказ от русских денег, земельной реформы и власти), мессианские и эсхатологические чаяния, связанные с ожиданием скорого возвращения Ойрот-хана. При этом западномонгольский (джунгарский) правитель XVII-XVIII вв. был мифологизирован в народном сознании как истинный правитель всех алтайцев и как посланник божества ӥч-Курбустана / Ак Бурхана, а о его возвращении возглашалось в особых ритуальных текстах - гимнах-молитвах јарлыкчылар (алт.) - 'пророков'.

5 Ниже различные смысловые блоки в схеме алтайской эсхатологии для наглядности заключены в квадратные скобки. 
цев под влиянием христианской книжной и устной традиции, со ссылкой на русские тексты [24, с. 47], не доказано и сомнительно. По всей видимости, заимствование произошло в гораздо более ранние времена (например, в Средневековье через тибетский буддизм и / или уйгурское манихейство), поскольку типичные эсхатологические тексты-пророчества были опубликованы В.И. Вербицким уже в І850-е гг. [Іо, с. II4] и В.В. Радловым в I860-е гг. [23, с. I67-I70; 28, с. 364-365]. Вероятно, к началу активной деятельности Алтайской духовной миссии (основана в I830 г.) жанр алтайских текстов-пророчеств уже сформировался. По крайней мере протоиерей В.И. Вербицкий не дает каких-то комментариев, из которых бы следовало, что такие тексты появляются у алтайцев под влиянием православия, хотя для него, как для священника и миссионера, подобная рецепция и восприимчивость алтайской культуры была бы, несомненно, важным свидетельством успеха Миссии.

Таким образом, проблематика культурного трансфера в алтайской эсхатологии может рассматриваться в нескольких аспектах:

- во-первых, очевидные буддийские центральноазиатские влияния и заимствования в эсхатологии и, шире, мифологии алтайцев [3о, с. 37];

- во-вторых, мифологизация других государств и народов (прежде всего, Китая и России) в мотивах эсхатологической войны и иноземного нашествия.

\section{Калъпы и айгулы: буддийские центральноазиатские влияния}

Ярким примером центральноазиатского культурного трансфера в алтайской эсхатологии является мифологическое представление о нескольких, сменяющих друг друга мировых катастрофах. Так, в соответствии с буддистским учением о кальпах 6 существует три вида разрушений: огнем, водой и ветром [8, с. 8I-86, 9I-93; 9, с. I80-I85, I95-197; 22, с. I96; 26, с. 3335, 57-65]. На Алтае бытуют похожие на это учение рассказы об айгулах (aлm.) - 'эсхатологических стихиях', наиболее известные в народе по пророчествам Боора, алтайского провидца, жившего в XVIII в. Так, в одной из опубликованных версий пророчества Боора написано:

6 Кальпа - единица измерения времени, глобальные временные периоды в индуизме и буддизме. 
Шесть стихий, шесть айгулов придет в движение в смутный век Боро Тююки: вода, огонь, ветер, мороз, земля и человек. Все стихии придут в неистовство. Так настанет последний срок - Боро Тююки [2, с. Іо9].

Рассказ об айгулах удалось в 2015 г. записать и мне:

(С.К.) - Много было, много пророчеств делали всяких разных, таких вещей очень много было. Очень интересные вещи рассказывала женщина, может, слышал ты, Коныр. Бабушка Коныр, вот она. Коныр, она, вот, говорила как раз вот это - айгул. Айгул, вот стихии, айгулдар. Про стихию, вот, наводнение было. И вот она говорила про четыре айгула. Стихия воды, стихия огня, стихия ветра и стихия холода, по-моему, льда, что ли. Нет, не льда, чтото такое. Надо мне вспомнить, потому что у меня где-то это опубликовано, я делала это. И вот он первый, вот этот первый айгул был, когда было, вот это наводнение было.

(Д.Д.) - Какое? Вот, недавно которое было?

(С.К.) - Ну, нет. Вот этот, про конец света говорим же. Потоп, всемирный потоп. <... Вот эти айгулы, и вот она перечисляла. И перечисляла вот эти признаки, мне его надо найти, я его делала, вот этот материал. И что там, вот, огонь, когда всё сгорает, ветер, когда всё уносит, и четвёртое же там было... Вода, огонь, ветер и что-то вот это прямо тоже вселенское что-то такое, когда всё там. <...> Вот этот разговор я вспомнила, знаешь, вот в связи с чем: когда у нас пожары-то начались, и землетрясение было, мы вспомнили про эти айгулыт

Таким образом, всемирный потоп прошлого был одним из айгулов. Л.И. Шерстовой удалось собрать алтайские эсхатологические представления, согласно которым Земля переживает второй период своего существования. Первая Земля погибла в потопе [36, с. I85; 37, с. 183]. Некоторые мои информанты, как мне удалось выяснить, говорили о нескольких эсхатологических потопах: один, который уже был, и второй - чайык, который

7 Записал Д.Ю. Доронин от С.К. Кыдыевой (1954 г.р., алтайка, сӧӧк Чагандык) в г. ГорноАлтайск 21.IO.20I5 г. Здесь и далее приведены тексты полевых материалов автора, записанные на русском языке, при этом с помощью информантов всякий раз выяснялось правильное написание алтайских имен и понятий. 
будет. Это будет потоп, предваряемый землетрясением, его ядовитые воды выступят из-под земли:

(Д.Д.) - Вот потоп, кстати, странно: ведь это же не предсказание о будущем, а то, что было в прошлом.

(Э.Е.) - Не, будущее, [это то], что чайык чыгар .

(Д.Д.) - То есть все-таки будет еще один потоп?

(Э.Е.) - Да. Чайык, и вот его ждали. Было землетрясение, потом нашли јер-былык9, и вот следующим шагом должно было быть как раз чайык. <..>

Ну, то, что конец света, один из возможных, видимо, вариантов - это то, что всех смоет, всех людей. Произойдет большой потоп, и уцелеют лишь только те люди, которые будут высоко в горах. И обычно подговаривали, что вот как раз вот люди, которые же проживают на Алтае, и уцелеют, так как они якобы очень высоко живут и тем самым будут спасены от потопа. А все низменности, ну, просто затопит, зальет всех людей, животных. <..>

Речь еще к тому же, что чайык - это не означает, что вода не придет откуда-то из ближайшего океана или моря. Она из-под земли выйдет. Это чайык, вот суть его в том, что он снизу выходит. То есть вода выйдет снизу, смоет всех, а люди, которые, вот, в горах, они останутся.

(Д.Д.) - А что это за вода из-под земли?

(Э.Е.) - Ну, из-под земли выйдет вода, никто не знает где, но она откуда-то из расщелины. Выйдет вода, и не просто вода, а вода с ядом ${ }^{\text {то }}$.

Таким образом, в отличие от библейской версии ${ }^{\mathrm{II}}$ потопа, который происходил от идущих ливней, в алтайских эсхатологических текстах со-

8 Чайык чыгар (алт.) - 'выступающий/появляющийся потоп'

9 Jep-былык / Кер балык - огромная и/или чудовищная рыба, согласно современным мифологическим представлениям алтайцев обитающая в подземных водах, появляющаяся в глубоких озерах как вестник войн/катастроф или конца света. Известны тексты, в которых эта рыба описывается как опора земли и/или ассоциируется с китом или даже мамонтом.

го Записал Д.Ю. Доронин от Э.В. Енчинова (1980 г.р., алтаец, сӧӧк Тодош) в г. ГорноАлтайск 06.ІІ.20I6 г.

II Хотя в Торе и, соответственно, в Библии говорится о развергающихся/открывающихся источниках великой бездны. Но удивительно, что комментаторы-библеисты говорят все-таки о ливне как о причине потопа, хотя очевидно, что тут можно увидеть две причины появления воды потопа, и, соответственно, возможно предположить две мифологические модели - потоп, приходящий сверху (воды дождя), и потоп, приходящий снизу (воды, проступающие изпод земли). 
общается не о дожде, а о воде, которая поднимается, все затопляя, из-под земли, как, например, встречаем и в пересказе бурханистской эсхатологии, сделанном в начале XX в. Д.А. Клеменцем:

Скоро с неба станет падать огонь, из земли будут бить ключи, которые затопят долины, а горы будут трястись и рассыпаться [І6, с. I57].

Возможно, что в мифологическом смысле это - древняя вода, относящаяся к зоне подземного, Нижнего мира. Вместе с этой водой на поверхность Среднего мира всплывают Кер-бальк и другие чудища Нижнего мира, которые, таким образом, являются вестниками грядущей катастрофы. В некоторых текстах особенность (нижней, подземной) воды потопа, ее катастрофичность и губительность подчеркиваются указанием на то, что она ядовита для всего живого на земле. Возможно, что «потоп, проступающий снизу», - это более архаичная, в сравнении с христианской, азиатская «модель потопа». Похожие параллели, согласно сообщению С.Ю. Неклюдова, обнаруживаются и у других азиатских народов: так, согласно калмыцкой сказочной традиции, «пуп земли» прикрыт гигантским быком; если его сдвинуть, хлынет вода и зальет землю. О воде, заливающей землю из земного отверстия, участники экспедиции под руководством С.Ю. Неклюдова записывали у дархатов (в частности, ими было зафиксировано мифологическое предание про озеро Хубсугул, которое возникло именно таким катастрофическим образом $\left.{ }^{\text {I2}}\right)$.

Другая распространенная версия эсхатологической катастрофы на Алтае - это гибель Земли в спускающемся с небес огне, в котором будет гореть вся поверхность земли и даже камни. В очистительной катастрофе водой и огнем Л.И. Шерстова обнаруживает несомненные ламаистские параллели, связанные с концуом света: гибель нынешней Вселенной представляется как ужасная катастрофа, когда «бедствия истребят почти всех живущих, после чего Земля очистится огнем и водой» [г7, с. г26; 37, с. г84].

Несомненные буддистские заимствования содержат и мифологические тексты, собранные и опубликованные в XIX в. протоиереем В.И. Вербицким

I2 Бат-Очир Дуужий. О том, как возникло озеро Хубсугул // Мифо-ритуальные традиции Монголии. Тексты интервью // Фольклор и постфольклор: структура, типология, семиотика. URL: http://www.ruthenia.ru/folklore/mongexp.htm\#207 (дата обращения: I2.I2.20I7). 
[Іо]. По моим наблюдениям, эти тексты, будучи переизданными значительным для Республики Алтай тиражом в 1993 г. (500о экз.), на волне алтайского «национально-культурного возрождения» снова были абсорбированы и реинтерпретированы живой, развивающейся мифологической традицией алтайцев. Необходимо добавить: мифологические тексты, собранные В.И. Вербицким в «Алтайских инородцах», вызывали критическое отношение уже в XIX в.: так, епископ Бийский Макарий (Невский) и переводчик при Алтайской духовной миссии, собиратель фольклора Михаил Чевалков полагали, что эти тексты нельзя считать чисто алтайскими, поскольку к алтайским воззрениям, несомненно, примешаны воззрения и имена буддийские и монгольские [ІІ, с. 305]. Вслед за ними такое же критическое отношение к миссионерскому источнику поддерживали Л.П. Потапов и В.А. Муйтуева [І9,

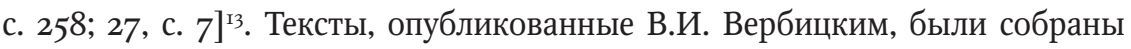
миссионером Стефаном Ландышевым от крещеного инородиа Ефима Корты, долгое время жившего среди теленгитов Чуйской степи (современная территория Кош-Агачского р-на), где, как считается, Ефим попал под влияние монголов-ламаистов $[27$, с. 7$]$. Однако во влиянии буддизма и монгольских мифологических представлений на алтайские нет ничего экстраординарного, такая рецепция в алтайской мифологии происходила неоднократно [5, с. 79; 22, с. 19-20; 30, с. 5; 36, с. I76-178], происходит она и в наше время. Поэтому

I3 Л.П. Потапов в вопросе о буддийском влиянии в текстах, опубликованных В.И. Вербицким, фактически просто повторяет А. Голубева, а В.А. Муйтуева ссылается на Л.П. Потапова. На мой взгляд, поиск «общеалтайской» или «чисто алтайской» мифологической традиции едва ли возможен, поскольку она развивалась и развивается во взаимодействии с другими (буддийскими, манихейскими, христианскими и пр.) традициями [30; 3I, c. 224; 36, с. I6I-I63]. Хотя Л.П. Потапов и В.А. Муйтуева едины в критическом отношении к миссионерскому источнику, они расходятся в оценках других источников. Так, Л.П. Потапов весьма критически относился к мифологическим текстам, записанным Л.Э. Каруновской в I929 г. от Мерея Танаша (крещеного шамана и јарлыкиы Кондратия Танашева) чуть ли не как к фантазиям [33, с. I44], но В.А. Муйтуева считала Мерея компетентным информатором, который просто не мог дать в корне неверные сведения [19, с. 26I]. Л.П. Потапов в несколько идеологическом духе тяготел к исследованию алтайского шаманизма как своего рода национальной религии саяно-алтайских народов $[27$, с. 6], теологию и ритуалы которой он пытался представить в виде стройной системы. Вероятно, по этой причине в меньшей степени его интересовали или даже вызывали критику материалы «гибридного типа», выбивающееся из общей картины «религии» алтайцев. Моя позиция близка к позиции алтайского исследователя и носителя традиции В.А. Муйтуевой, однако я иду чуть дальше, предлагая рассматривать тексты, собранные Ст. Ландышевым и В.И. Вербицким, как часть и репрезентацию локальных вариантов алтайской мифологической системы, в большей степени насыщенных заимствованиями из буддийской традиции. 
я считаю допустимым рассматривать опубликованные В.И. Вербицким тексты (пусть и содержащие очевидные ламаистские заимствования) в качестве репрезентирующих одну из возможных алтайских эсхатологических субтрадиций. Такой авторитетный современный исследователь, как Л.И. Шерстова, полагает, что было бы неверным рассматривать алтайскую мифологию / религию только как шаманистическую, и указывает на бытование алтайских мифологических представлений, в которых ламаистское мировоззрение проявляется детально и выразительно [36, с. г6г].

Буддийские элементы в алтайской эсхатологии - частный случай обширной темы взаимовлияний алтае-тюркского (изначально шаманистского) и буддийского (монгольского и тибетского) миров. Космогонические, этиологические и эсхатологические мифы, имена мифологических персонажей (Бурхан, богатыри Мангдышире и Майдере, девица Эрьке-шудюн), ритуальные предметы и практики (магические книги-судуры, подкуривание можжевельником-арчыном, возлияния молоком и маслом, жертвенники кӥре и тагылы, каменные кучи-обоо, светильники-јула, статуэтки бодхисатв) свидетельствуют о включении в алтайскую мифологию и, в частности, в эсхатологию буддистских элементов. Мангдышире и Майдере (алтайские версии имени бодхисаттвы Манджушри и имени грядущего Будды Майтреи) сражаются в конце времен с хозяином подземного мира Эрликом и его богатырями, в это же время, согласно некоторым современным эсхатологическим представлениям, скрытая магическая книга Судур бичик (алтайская калька слова «сутра») являет себя людям.

Помимо буддистских заимствований в алтайской мифоритуальной системе велико влияние культурного трансфера прежних монгольских империй на самосознание современных алтайцев. Как известно, в прошлом кочевые предки алтайцев входили в состав государств Чингисхана, его потомков, а позже были конфедератами джунгар (ойратов). По прошествии двух с лишним веков после падения Джунгарского ханства монгольская (ойратская) история присваивается исторической памятью алтайцев и воспринимается как «золотой век» их прошлого. Контекст республиканской науки дает обоснование этому присвоению, создавая перформативные описания алтайского этногенеза [32, с. 38]. «Родословие каждой алтайской семьи восходит к Ойротской эпохе», - заключает алтайский востоковед и Эл башчы алтайского народа Бронтой Бедюров [6, с. 22]. 
В контексте «низовой» повседневности алтайцы, конечно же, отделяют себя от монголов посредством таких актуальных культурных практик, как трансграничная торговля и конокрадство, а также из-за наличия «естественного» рубежа госграницы и разницы в языке и религии. Однако на уровне личного присвоения легендарной истории алтайцы связывают себя с монголами: мне неоднократно приходилось слышать о «монгольских родах» среди алтайцев (могол, ойрот, меркит, тербет, майман, тумат, чорос), среди сельского населения популярны рассказы о магической книге Судур Бичик, о горных крепостях Амурсаны и мессианско-эсхатологические представления о грядущем Шӱнй или Ойрот-Каане. По словам одного из моих информантов, «за плечами каждого алтайца стоит Чингисхан», а Телецкое озеро считается местом захоронения конницы, унесшей в глубины тайну погребения хана, который в конце времен вновь вернется к своему народу. Ревизия ойратского наследия в спорах о будущем алтайского народа - популярная тема молодежной блогосферы [34].

\section{Кыдаты как эсхатологический народ}

Эсхатологическая война - одна из самых разработанных тем в алтайской эсхатологии. Существует несколько точек зрения на то, между кем произойдет эта последняя битва. Самая популярная версия связывает ее с кыдатами - китайцами, что, по всей видимости, является исторической памятью о геноциде джунгар и на Алтае, устроенном китайцами в XVIII в. Один из моих информантов в ответ на расспросы о китайцах и последнем веке вспомнил старую алтайскую пословицу:

Эрдине сӧӧги јӱујеринде, эрдин сӧӧги Чан јеринде - ‘кости боевого коня должны лежать на поле битвы, кости хорошего мужчины должны лежать остаться в Чан' (алm). Это Чина, Китай. Значит, вся наша история - это всё было противостояние кочевников с Китаем ${ }^{14}$.

О китайцах как эсхатологическом народе можно прочесть уже в записях мифологических текстов, сделанных в г86о-х гг. миссионером Стефаном Ландышевым и изданных затем протоиереем и этнографом

I4 Записал Д.Ю. Доронин от Б.Т. Самыкова (І947 г.р., алтаец, сӧӧк Кергил, родом из с. Каспа Шебалинского р-на Республики Алтай) в г. Горно-Алтайске 3І.Іо.2ог6 г. 
В.И. Вербицким. В одном из этих текстов ${ }^{15}$ богатырь-небожитель ТюрунМузыкай, воплотившись в человека Тямаа-Тюрун, после победы над демоническим противником странствует по всей земле, пока китайский хан не узнает за его человеческим обличием божество - правителя среднего из 99 миров. В награду перед своим уходом он благословляет хана, оставляя ему эсхатологическое знание-наказ и небесную книгу о происхождении мира: «Но смотри, чтобы с тобой никто не воевал и ты ни с кем не воюй и не имей связи с другими землями. Когда будет война других с царством твоим, тогда близка будет кончина века!» [Iо, с. Іог]. Вся судьба мира - и его начало, и его конец - оказывается (в представлении алтайца-ойрота XIX в.) в руках Китая.

К текстам об эсхатологической войне с китайцами примыкают другие тексты «китайской легенды» ${ }^{16}$ на Алтае, например, завет телеутских военных вождей Абака, Мачика и / или алтайского мудреца и провидца Боора никогда не поселяться рядом с китайцами и не откочевывать в их земли. В противном случае алтайский народ исчезнет, растворившись среди китайцев.

(С.Б.) - Да, есть такое. Там не конец света, там будет война, при которой будет преобладать и, в конце концов, победит кара калык - черный народ, имеется в виду Китай. Кара кыдат, ну, то есть черный Китай победит.

(Д.Д.) - А с кем он будет воевать?

(С.Б.) - Но, наверное, со всем остальным <миром>.

(Д.Д.) - А Вы слышали такое, что будет последняя битва между Катунью и Бией?

(С.Б.) - Именно об этой битве и говорится. Но имеется в виду не в прямом смысле о битве, но еще говорят: «Не меч победит мир, мир победит труд». Имеется в виду китайский труд. Я так думаю ${ }^{17}$.

I5 Уже в г88о-е гг. этнографы комментировали мифологические тексты, собранные Ст. Ландышевым, не как чисто алтайские, поскольку к алтайским воззрениям несомненно примешаны воззрения и имена буддийские и монгольские [Іі, с. 305].

I6 Под «китайской легендой» здесь понимается комплекс мифологических представлений о китайском нашествии, кыдатах (китайцах) и о Китае как об эсхатологическом акторе. См. также о «китайской легенде» на примере русской эсхатологии: [3, с. I36-I43; 7, с. 206-215].

I7 Записал Д.Ю. Доронин от Б.Т. Самыкова (г947 г.р., алтаец, сӧӧк Кергил, родом из с. Каспа Шебалинского р-на Республики Алтай) в г. Горно-Алтайске 31.І0.2016 г. 
А о китайцах вот этот, сын Солтона - Боор, тоже предсказатель Майманов, он говорил. Рерих о нем писал, что он спрашивал: «Кто умный на Алтае?» - это Бооре. Он все время «Бооре» пишет: «Все алтайцы, все тюрки знают его имя». Вот, он что сказал. Даже и не он, а Мочик и Абак, предводители алтайские: вы не старайтесь примкнуться к китайцам, их так много, что вы себя потеряете. В смысле, как народ. Почему вы должны присоединиться к русскому, потому что когда-нибудь я свой народ разыщу по глазам, что это тюрки. А если присоединить к китайцам, вы почти ж-то визуально одинаковые, и вы там растворитесь. <..> То есть этот народ, кыдаты, говорит, китайцы - их так много, что вы среди них растворитесь. И через какое-то время я найду вас по волосам, то есть черные волосы среди чужих, среди славян. <...> Они все время остерегали: только не с китайцами! ${ }^{18}$

В одном из записанных мною в 2003 г. текстов кара-кыдаты сравниваются с пожирающей все на своем пути саранчой ${ }^{19}$; в подобных случаях эсхатологические ожидания «запускаются» геополитическими страхами на Алтае в связи с возможной китайской экспансией. Конкретным событием, актуализировавшим фольклорные представления в качестве объяснительной модели в начале XXI в., было решение о строительстве газопровода и автомагистрали через плато Укок.

В других рассказах китайцы трактовались как кара калык, кара албаты - 'черный народ’, кара-башту албаты - 'народ черноголовых', побеждающий все другие народы в конце времен. При этом некоторые информанты из с. Каспа и с. Ортолык объединили алтайцев и китайцев в этот единый эсхатологический народ-победитель, который станет править всем миром в конце веков. В этом случае последняя битва интерпретировалась как война белой и монголоидной рас.

\section{Две войны}

Весьма распространенные на Алтае предсказания сообщают о двух последних тяжелых войнах - средней войне с Запада, которую можно будет

I8 Записал Д.Ю. Доронин от Н.М. Киндиковой (1953 г.р., алтайка, сӧӧк Кара Майман) в г. Горно-Алтайске 31.10.2016 г.

I9 Представления о саранче в современных алтайских эсхатологических тестах, возможно, заимствованы из библейских мифологических образов (см., например, Исх. Іо: І2-15; Иоил. I: 6; 2: 5; Откр. 9: 3-ІІ). 
пережить, и большой, последней войне с Востока, которая сметет все.

Ну, и там, там говорилось, и вот это часто, постоянно вспоминается об этом, что война, которая придет с Запада, - это будет средняя война. А вот эта последняя война - она придет с Востока, вот примерно так. Јаан, большая война придет с Востока. Вот такие моменты были ${ }^{20}$.

Один из моих информантов, пожилой алтаец, вспоминает пересказ своей бабки того, что пророчествовал о будущих войнах и о последней войне странствующий тибетский лама, заехавший к ним в село:

Вот бабка рассказывала: «Приезжал, - говорит, - до четырнадцатого года, приезжал, - говорит, - алтаец к нам. Лама, он приехал с Тибета. В Апшуяхту приезжал, на белом коне. <... В Вот два дня он рассказывал. У него такой большой книжка, два дня, два ночи говорил он. Вот он, он свой книгу открывает - вот говорит, говорит. Вот рассказывает это вот: «Вот так вот, вот, вот, вот... чё будет». И вот его сказание все сбылось!

Вот эту, Отечественную, войну он сказал вот. Как же он сказал? Скоро, говорит, начнется война, кровь прольется. А эта империалистическая война еще не началась.

Ну, ладно, говорит, это четырнадцатый год. Потом, говорит, снова начнется движение народа, кровь прольется. Потом немного народ нормально поживет. Потом, говорит, вот это - репрессии, все это, кровь прольется, и потом большая война, говорит, начнется.

После нее народ хорошо будет жить. Но немного будет жить хорошо, говорит. А потом, говорит, сказал, черный народ начнется, вот движение, говорит, знаешь, нет? Кара албаты - это вот чеченцы, вот эти, вся вот эта кровь прольется. После этого немного [мира] будет, а потом война, говорит, начнется. Исшо, говорит, война, вот эта, третья мировая. Бабка вот так сказала. Вот эта третья мировая война! ${ }^{21}$

20 Записал Д.Ю. Доронин от С.К. Кыдыевой (1954 г.р., алтайка, сӧӧк Чагандык) в г. ГорноАлтайск 2І.10.2015 г.

2 І Записал Д.Ю. Доронин от С.В. Анакова (I96I г.р., алтаец, сӧӧк Кергил) в с. Каспа Шебалинского р-на Республики Алтай І8.09.201г г. 
В большинстве случаев «войну с Востока» информанты трактовали именно как китайское нашествие. В некоторых версиях напутствия покидающего свой народ Ойрот-Каана тоже присутствует этот мотив: «Уходя, Ойрот-Каан сказал: Если приду со стороны заката солнца - мягко пройду. Если приду со стороны восхода солнца - у мужчин отрезая кончик большого пальиа, пройду, у женщины срезая кончик груди, пройду» [2, с. 63]. «Китайская легенда» при этом интерпретируется через легенды ойротского цикла: грядущий Ойрот отождествляется с катастрофическим нашествием с Востока.

\section{Кровавые реки: традиционные мотивы в современном контексте}

Наиболее яркий мотив в описании эсхатологической битвы - кровавые реки; в зависимости от исторического контекста эсхатологическими противниками могли считаться русские или китайцы. Так, например, в некоторых текстах јарлыкчы первой четверти XX в. сообщалось о грядущей битве Ойрота и его народа с русскими при слиянии Бии и Катуни. Борьба будет столь жестока, что Катунь потечет кровью, а по Иртышу попльвут трупы убитых воинов [І2, с. I4I]. Этот же мотив можно встретить при описании кровавых битв прошлого или в предсказании Боора о последнем веке [2, c. IO9].

Приход русских и приход жыдатов сопоставляются в одном мифологическом рассказе, записанном мною от информанта-тубалара в Артыбаше: при приходе белого леса (берез) и белых людей с Алтая уходят алмысы, а если придут китайцы, то Алтай покинут его духи-ээзи. В этом эсхатологическом рассказе актуализировался мотив «уходящей чуди», мифологизировались современные геополитические страхи и текстуализировались воспоминания о советско-китайском конфликте на острове Даманский.

Подобным же образом «китайская легенда» актуализировалась во время китайско-вьетнамской войны 1979 г.: по словам информанта, на Алтае многие считали, что СССР ввяжется в конфликт на стороне Вьетнама, и Алтая, как приграничную территорию, это коснется в первую очередь. Ожидание войны с китайцами-кыдатами воспринималось алтайцами не только в политическом, но и в эсхатологическом контексте. По воспоминаниям информантов, актуализировалось эсхатологическое белге: например, красный закат интерпретировался как знак приближающейся военной 
катастрофы, бойни на Алтае. Катастрофические настроения и эсхатологические ожидания проявились в детской среде: так, в Усть-Канском районе мальчики смешанными русско-алтайскими дружескими ватагами строили в лесу стены из кольев и землянки для партизанской обороны во время ожидаемого вскоре китайского нашествия.

\section{Заключение}

Алтайская эсхатология, включая большой «мессианский компонент» и пласт воспоминаний о «золотом веке» Джунгарского правления, легендарно-исторична, поскольку связана с постоянными переживаниями, разговорами и дискуссиями алтайцев о своем великом прошлом, о судьбе, направлении и пути развития своего народа. Время алтайской эсхатологии отчасти близко «историческому» времени былины в его описании С.Ю. Неклюдовым: здесь также присутствует «осознание исторического процесса как воспроизведение старого, а не создание нового», и в описании грядущей эсхатологической эпохи «характерно обращение идеала назад, к прошлому» [2I, с. 38-39], «золотому веку» правления Шӱнӥ или Ойрот-Каана. Эсхатологическое знание о грядущем парадоксальным образом определяется легендарно-историческим прошлым конкретных событий XVIII в. (войны, междоусобица, китайское/монгольское нашествие, переселение этнических групп, бегство правителя) и даже «биографическим» временем прошлого [2I, c. 36] реально живших людей (Ойрот-Каан, Шӱнй, Амыр-Санаа, Эдиен-Каан, Боор), с которыми связывается теперь эсхатологическое знание. Как было показано, немалую роль в формировании сюжетно-мотивного фонда алтайской эсхатологии играет культурный трансфер. 


\section{Список литературы}

I Aлтай кеп-куучындар / Алтайские мифы // сост. Е.Е. Ямаева, И.Б. Шинжин. Горно-Алтайск: ИЧП «Ак Чечек», I994. 4I4 с. Алтайские исторические предания Ойротской эпохи: XVII-XIX вв. / пер. с алт. Е.В. Королёвой, гл. ред. и сост. Б.Я. Бедюров. Новосибирск: Гео, 20I4. 203 с. Ахметова М.В. Конец света в отдельно взятой стране: Религиозные сообщества постсоветской России и их эсхатологический миф. М.: ОГИ, 20Іо. 333 с. Басилов В.Н., Потапов Л.П. Тюркоязычных народов мифология // Мифы народов мира: Энциклопедия: в 2 т. М.: Сов. Энциклопедия, І988. Т. 2. С. 536-54I. Батьянова Е.П. Телеутская версия бурханизма // Этнографическое обозрение 2005. № 4. С. 70-85.

6 Бедюров Б.Я. Алтайские исторические предания Ойротской эпохи // Алтайские исторические предания Ойротской эпохи: XVII-XX вв. Новосибирск: Гео, 2014. C. 5-22.

7 Бессонов И.А. Русская народная эсхатология: история и современность. М.: Гнозис, 2014. 333 с.

8 Васубандху. Абхидхармакоша. Гл. III. / близкий к тексту пер. с тибетского Б.В. Семичева, М.Г. Брянского. Улан-Удэ: Бурят. кн. изд-во, І98о. 260 с. Васубандху. Абхидхармакоша (Энциклопедия Абхидхармы). Раздел третий: Учение о мире / пер. с санскрита Е.П. Островской, В.И. Рудого. СПб.: Изд-во «Андреев и сыновья», г994. 335 с. Вербиикий В.И. Алтайские инородцы: Сборник этнографических статей и исследований. М.: Тов-во скоропечатни А.А. Левенсон, I893. XIV, 22I с. Голубев А. Предисловие // Православный собеседник. І886. Ч. І. С. 304-306. Данилин А.Г. Бурханизм. Из истории национально-освободительного движения в Горном Алтае. Горно-Алтайск: Ак Чечек, г993. 204 с. Доронин Д.Ю. Религиозные лидеры и течения «алтайской веры»: герменевтика наследия и вариативность // Философия в современном мире: диалог мировоззрений: Материалы VI Российского философского конгресса (Нижний Новгород, 27-30 июня 2012 г.): в 3 т. Н. Новгород: Изд-во Нижегородского гос. ун-та им. Н.И. Лобачевского, 20I2. Т. І. С. 438.

I4 Доронин Д.Ю., Енчинов Э.В. Сибирское «поле» конца света: социальные ситуации алтайской эсхатологии // XII Конгресс антропологов и этнологов России: сб. материалов. Ижевск, 3-6 июля 2017 г. / отв. ред. А.Е. Загребин, М.Ю. Мартынова. М.; Ижевск: ИЭА РАН, УИИЯЛ УрО РАН, 2ОІ7. С. 383-384.

I5 Енчинов Э.В. Эсхатологические мифы в современной алтайской культуре // I Сибирский форум фольклористов: Тезисы докладов / Сер. «Памятники фольклора народов Сибири и Дальнего Востока». Новосибирск: ООО «Академиздат», 2016. C. $156-158$. 
Клемени Д.А. Из впечатлений во время летней поездки в Алтай в 1904 году // Известия ИРГО / под ред. А.А. Достоевского. І905. Вып. І, кн. 6г. C. I55-I59.

I7 Кочетов А.Н. Ламаизм. М.: Наука, І973. г99 с.

I8 Львова Э.Л., Октябрьская И.В., Сагалаев А.М., Усманова М.С. Традиционное мировоззрение тюрков Южной Сибири. Пространство и время. Вещный мир. Новосибирск: Наука. Сибирское отд., І988. 224 с.

I9 Муйтуева В.А. О сборнике В.И. Вербицкого «Алтайские инородцы» // Алтайские инородцы. Горно-Алтайск: Ак-Чечек, г993. С. 257-269. Неклюдов С.Ю. Кальпа // Мифы народов мира: Энциклопедия: в 2 т. М.: Сов. Энциклопедия, г987. Т. г. С. І96. Неклюдов С.Ю. Поэтика эпического повествования: пространство и время. М.: Форум, 20I5. 215 c. Несказочная проза алтайцев // Памятники фольклора народов Сибири и Дальнего Востока / сост. Н.Р. Ойноткинова, И.Б. Шинжин, К.В. Яданова, Е.Е. Ямаева. Новосибирск: Наука, 20II. Т. 30.565 с.

23 Образцы народной литературы тюркских племен, живущих в Южной Сибири и Дзунгарской степи, собранные В.В. Радловым. СПб.: Тип. Императорской Академии наук, І866. Ч. г: Поднаречия Алтая. С. І13-I59.

24 Ойноткинова Н.Р. Эсхатологические мифы алтайцев: «чудесный мир» перед концом света // Мельниковские чтения: Материалы Седьмой межрегиональной науч.-практ. конф. (Новосибирск, І9 февраля 2015 г.) / науч. ред. Н.В. Леоновой. Новосибирск: НГОНБ, 2ОI5. С. 44-49.

25 Ойноткинова Н.Р., Ямаева Е.Е. Несказочная проза алтайцев / сост. Н.Р. Ойноткинова, И.Б. Шинжин, К.В. Яданова, Е.Е. Ямаева. Новосибирск: Наука, 20II. С. II-46.

26 Островская Е.П., Рудой В.И. Проблемы исследования буддийской космологии // Васубандху. Абхидхармакоша (Энциклопедия Абхидхармы). Раздел третий: Учение о мире. СПб.: Изд-во «Андреев и сыновья», г994. С. 6-66.

27 Потапов Л.П. Алтайский шаманизм. Л.: Наука, І99г. 319 с.

28 Радлов В.В. Из Сибири: Страницы дневника. М.: Наука. Главная редакция восточной литературы, г989. 749 с.

29 Религиозные деноминации в Республике Алтай / отв. ред. Н.О. Тадышева. ГорноАлтайск: ООО «Горно-Алтайская типография», 2015. 479 с.

30 Сагалаев А.М. Мифология и верования алтайцев. Центральноазиатские влияния. Новосибирск: Наука, І984. І2г с.

3I Стеблева И.В. К реконструкции древнетюркской религиозно-мифологической системы // Тюркологический сборник. М.: Наука, І97І. С. 213-226. 
32 Тадина Н.А. «Ойрот» как символ государственности в этническом сознании алтайцев // Единая Калмыкия в единой России: через века в будущее (матер. конф.). Элиста: ЗАО «НПП «Джангар», 2009. Ч. І. С. 424-427.

33 Токарев С.А. Пережитки родового культа у алтайцев // Труды Института этнографии им. Н.Н. Миклухо-Маклая. Новая серия / отв. ред. С.П. Толстов. М.; Л., І947. T. I. C. 139-I58.

34 Торбоков A. Земля ойратов - Алтай // ARD: портал деловой информации. 3.02.2015. URL: http://asiarussia.ru/articles/6008/ (дата обращения: I2.I2.20I7).

35 Тюхтенева С.П. Земля. Вода. Хан Алтай: этническая культура алтайцев в XX в. Элиста: Изд-во КалмГУ, 2009. 167 с.

36 Шерстова Л.И. Бурханизм: истоки этноса и религии. Томск: Томский гос. ун-т, 20IO. 285 c.

37 Шерстова Л.И. Эсхатология раннего бурханизма: из опыта реконструкции традиционного этнического самосознания // Вестник Томского государственного университета. История. 20I3. № 3 (23). С. I8I-I85.

38 Ябыштаев Т.С. От национального движения алтайцев к образованию Республики Алтай // История и современность Республики Алтай (матер. конф.). ГорноАлтайск: Комитет по делам архивов Республики Алтай, 20I2. С. II-I4. 


\section{References}

Altaj kep-kuuchyndar, Altajskie mify [Altay kep-kouchinga, Altai myths], comp.

E.E. Yamaeva, I.B. Shinzhin. Gorno-Altajsk, IChP “Ak Chechek” Publ., I994. 4I4 p. (In Russ.)

Altajskie istoricheskie predaniya Ojrotskoj epohi: XVII-XIX vv. [Altai historical legends Oyrotskih epoch: $18^{\text {th }}-19^{\text {th }}$ centuries], trans. from Altaic by E.V. Korolyovaya, ed. B.Ya Bedyurov. Novosibirsk, Geo Publ., 20I4. 203 p. (In Russ.)

Ahmetova M.V. Konec sveta v otdel'no vzyatoj strane: Religioznye soobshchestva postsovetskoj Rossii i ih eskhatologicheskij mif [The end of the world in a single country: Religious communities of post-Soviet Russia and their eschatological myth]. Moscow, OGI Publ., 20IO. 333 p. (In Russ.)

Basilov V.N., Potapov L.P. Tyurkoyazychnyh narodov mifologiya. Mify narodov mira: Enciklopediya: $\mathbf{2} 2 \mathrm{t}$. [Myths of the peoples of the world: encyclopedia: in 2 vols.] Moscow, Sovetskaya Enciklopediya Publ., 1988, vol. 2, pp. 536-54I. (In Russ.) Bat'yanova E.P. Teleutskaya versiya burhanizma [Teleut version of Burganism]. Etnograficheskoe obozrenie [Ethnographic review], 2005, no 4, pp. 70-85. (In Russ.) Bedyurov B.Ya. Altajskie istoricheskie predaniya Ojrotskoj epohi [Altai historical legends of the Oyrotskaya epoch]. Altajskie istoricheskie predaniya Ojrotskoj epohi: XVII$X X v v$. [Altai historical legends Oyrotskih epoch: $17^{\text {th }}-2 \mathrm{O}^{\text {th }}$ centuries] Novosibirsk, Geo Publ., 20I4, pp. 5-22. (In Russ.)

7 Bessonov I.A. Russkaya narodnaya eskhatologiya: istoriya i sovremennost'. [Russian folk eschatology: history and modernity]. Moscow, Gnozis Publ., 20I4. 333 p. (In Russ.)

8 Vasubandhu. Abhidharmakosha. Gl. III. [Abhidharmakośakārikā. Ch. III], trans. from Tibetan by B.V. Semichev, M.G. Bryansky. Ulan-Ude, Buryat. kn. izd-vo Publ., I980. 260 p. (In Russ.) Vasubandhu. Abhidharmakosha (Enciklopediya Abhidharmy). Razdel tretij: Uchenie o mire [Abhidharmakosha (Encyclopedia of Abhidharma). Section three: the Doctrine of peace], trans. from Sanskrit E.P. Ostrovskay, V.I. Rudov. St. Petersburg, Izd-vo “Andreev i synov'ya” Publ., I994. 335 p. (In Russ.) Verbickij V.I. Altajskie inorodcy: Sbornik etnograficheskih statej i issledovanij [Altai foreigners: Collection of ethnographic articles and studies]. Moscow, Tovarishchestvo skoropechatni A.A. Levenson Publ., I893. XIV, 221 p. (In Russ.) Golubev A. Predislovie [Foreword]. Pravoslavnyj sobesednik [The Orthodox interlocutor], I886, ch. I, pp. 304-306. (In Russ.) Danilin A.G. Burhanizm. Iz istorii nacional'no-osvoboditel'nogo dvizheniya v Gornom Altae [Burkhanism. From the history of the national liberation movement in the Altai Mountains]. Gorno-Altajsk, Ak Chechek Publ., I993. 204 p. (In Russ.)

I3 Doronin D.Yu. Religioznye lidery i techeniya "altajskoj very”: germenevtika naslediya i variativnost' [Religious leaders and the trends of "altaic belief": the hermeneutics of the heritage and variativity]. Filosofiya $v$ sovremennom mire: dialog mirovozzrenij: 
Materialy VI Rossijskogo filosofskogo kongressa (Nizhnij Novgorod, 27-30 iyunya 2012 g.): v 3 t. [Philosophy in the modern world: dialogue of worldviews: Proceedings of the $4^{\text {th }}$ Russian Philosophical Congress (Nizhny Novgorod, June 27-30, 20I2): in 3 vols.] N. Novgorod, Izd-vo Nizhegorodskogo gosuniversiteta im. N.I. Lobachevskogo Publ., 20I2, vol. I, p. 438. (In Russ.) Doronin D.Yu., Enchinov E.V. Sibirskoe “pole” konca sveta: social'nye situacii altajskoj eskhatologii [Siberian apocalyptic "field": social situations of Altai eschatology]. XII Kongress antropologov i etnologov Rossii: sb. materialov. Izhevsk, 3-6 iyulya $2017 \mathrm{~g}$. [The $12^{\text {th }}$ Congress of anthropologists and ethnologists of Russia: proceedings. Izhevsk, 3-6 July 20I7], eds. A.E. Zagrebin, M.Yu. Martynova. Moscow; Izhevsk, IEA RAN, UIIYaL UrO RAN Publ., 20I7, pp. 383-384. (In Russ.)

Enchinov E.V. Eskhatologicheskie mify v sovremennoj altajskoj kul'ture [Eschatological myths in contemporary Altai culture]. I Sibirskij forum fol'kloristov: Tezisy dokladov [I ${ }^{\text {st }}$ Siberian forum of folklorists: Abstracts]. Novosibirsk, OOO “Akademizdat" Publ., 20I6, pp. I56-I58. (In Russ.) Klemenc D.A. Iz vpechatlenij vo vremya letnej poezdki v Altaj v I904 godu [The glimpses of the summer trip to Altai in I904]. Izvestiya IRGO [Proceedings of IRGO], ed. A.A. Dostoevsky. I905, issue I, book 6I, pp. I55-I59. (In Russ.)

I7 Kochetov A.N. Lamaizm [Lamaism]. Moscow, Nauka Publ., I973. I99 p. (In Russ.)

I8 L'vova E.L., Oktyabr'skaya I.V., Sagalaev A.M., Usmanova M.S. Tradicionnoe mirovozzrenie tyurkov Yuzhnoj Sibiri. Prostranstvo i vremya. Veshchnyj mir [Traditional world outlook of the Turki in South Siberia. Space and time. Material world]. Novosibirsk, Nauka. Sib. otd-nie Publ., I988. 224 p. (In Russ.)

I9 Mujtueva V.A. O sbornike V.I. Verbickogo "Altajskie inorodcy” [On V.I. Verbic]. Altajskie inorodcy [Altai aliens]. Gorno-Altajsk, Ak-Chechek Publ., I993, pp. 257-269. (In Russ.)

Neklyudov S.Yu. Kal'pa. Mify narodov mira: Enciklopediya: $v 2 t$. [Myths of the peoples of the world: encyclopedia: in 2 vols.]. Moscow, Sovetskaya Enciklopediya Publ., I987, vol. I, p. I96. (In Russ.)

2I Neklyudov S.Yu. Poetika epicheskogo povestvovaniya: prostranstvo i vremya [Poetics of epic narrative: space and time]. Moscow, Forum Publ., 2015. 215 p. (In Russ.)

22 Neskazochnaya proza altajcev [Non-Fairytalish Fiction of the Altai People]. Pamyatniki fol'klora narodov Sibiri i Dal'nego Vostoka [Folklore monuments of the peoples of Siberia and the Far East], comp. N.R. Ojnotkinova, I.B. Shinzhin, K.V. Yadanova, E.E. Yamaeva. Novosibirsk, Nauka Publ., 20II. Vol. 30. 565 p. (In Russ.)

23 Obrazcy narodnoj literatury tyurkskih plemen, zhivushchih v Yuzhnoj Sibiri i Dzungarskoj stepi, sobrannye V.V. Radlovym [Samples of folk literature of the Turkic tribes living in southern Siberia and Dzungarian steppe collected by V. V. Radlov]. St. Petersburg, Tipografiya Imperatorskoj Akademii nauk Publ., I866. Ch. I: Podnarechiya Altaya, pp. II3-I59. (In Russ.) 
24 Ojnotkinova N.R. Eskhatologicheskie mify altajcev: "chudesnyj mir" pered koncom sveta. Mel'nikovskie chteniya: Materialy Sed'moj mezhregional'noj nauch.-prakt. konf. (Novosibirsk, I9fevralya 20I5 g.) [Melnikovsky reading: proceedings of the Seventh scientific conference (Novosibirsk, I9 February 2015)], ed.

N.V. Leonovoj. Novosibirsk, NGONB Publ., 20I5, pp. 44-49. (In Russ.)

25 Ojnotkinova N.R., Yamaeva E.E. Neskazochnaya proza altajcev [Fairy-tale prose of the Altai people], comp. N.R. Ojnotkinova, I.B. Shinzhin, K.V. Yadanova, E.E. Yamaeva. Novosibirsk, Nauka Publ., 20II, pp. II-46. (In Russ.)

26 Ostrovskaya E.P., Rudoj V.I. Problemy issledovaniya buddijskoj kosmologii [The aspects of the study of the Buddhist cosmology]. Vasubandhu. Abhidharmakosha (Enciklopediya Abhidharmy). Razdel tretij: Uchenie o mire [Vasubandhu. Abhidharmakosha (Encyclopedia of Abhidharma). Section three: the Doctrine of peace]. St. Petersburg, Izd-vo “Andreev i synov'ya” Publ., I994, pp. 6-66. (In Russ.) Potapov L.P. Altajskij shamanism [Altai shamanism]. Leningrad, Nauka Publ., I99I. 3I9 p.

28 Radlov V.V. Iz Sibiri: Stranicy dnevnika [From Siberia: the pages of the diary]. Moscow, Nauka. Glavnaya redakciya vostochnoj literatury Publ., I989. 749 p. (In Russ.)

29 Religioznye denominacii $v$ Respublike Altaj [Religious denominations in the Republic of Altai], ed. N.O. Tadysheva. Gorno-Altajsk, OOO “Gorno-Altajskaya tipografiya” Publ., 20I5. 479 p. (In Russ.)

30 Sagalaev A.M. Mifologiya i verovaniya altajcev. Central'no-aziatskie vliyaniya [Mythology and beliefs of the Altai people. Central Asian influences]. Novosibirsk, Nauka Publ., I984. I2I p. (In Russ.)

3I Stebleva I.V. K rekonstrukcii drevnetyurkskoj religiozno-mifologicheskoj sistemy [On the recontruction of the Old Turkian religious and mythological systems]. Tyurkologicheskij sbornik [Turkological collection]. Moscow, Nauka Publ., I97I, pp. 213-226. (In Russ.)

32 Tadina N.A. "Ojrot" kak simvol gosudarstvennosti v etnicheskom soznanii altajcev ["Ojrot" as a symbol in the national and ethnical consciousness of the Altai people]. Edinaya Kalmykiya v edinoj Rossii: cherez veka v budushchee (mater. konf.) [United Kalmykia in the unified Russia: across ages and towards the future (conference proceedings)]. Elista, ZAO “NPP «Dzhangar” Publ., 2009, ch. I, pp. 424-427. (In Russ.)

33 Tokarev S.A. Perezhitki rodovogo kul'ta u altajcev [The remnants of the ancestral cult of the Altai people]. Trudy Instituta etnografii im. H.H. Mikluho-Maklaya. Novaya seriya [Proceedings of the Institute of Ethnography. H. H. Mikluho-Maclay. New series], ed. S.P. Tolstov. Moscow, Leningrad, I947, vol. I, pp. I39-I58. (In Russ.)

34 Torbokov A. Zemlya ojratov - Altaj [The world of Ojrot - Altai]. ARD: portal delovoj informacii [ARD: business information portal]. 3.02.2015. Available at: http:// asiarussia.ru/articles/6008/ (Accessed I2 December 20I7). (In Russ.) 
35 Tyuhteneva S.P. Zemlya. Voda. Han Altaj: etnicheskaya kul'tura altajcev v XX v. [Land. Water. Khan Altai: ethnic culture of the Altai in the $20^{\text {th }}$ century] Elista, Izd-vo KalmGU Publ., 2009. I67 p. (In Russ.)

36 Sherstova L.I. Burhanizm: istoki etnos a i religii [Burkhanism: the origins of ethnicity and religion]. Tomsk, Tomskij gosudarstvennyj universitet Publ., 20IO. 285 p. (In Russ.)

37 Sherstova L.I. Eskhatologiya rannego burhanizma: iz opyta rekonstrukcii tradicionnogo etnicheskogo samosoznaniya [Eschatology of the early Burhanism: reconstructing traditional etnical self-consciousness]. Vestnik Tomskogo gosudarstvennogo universiteta. Istoriya, 20I3, no 3 (23), pp. I8I-I85. (In Russ.)

38 Yabyshtaev T.S. Ot nacional'nogo dvizheniya altajcev k obrazovaniyu Respubliki Altaj [From the national movement of the Altai people towards Altai republic]. Istoriya i sovremennost' Respubliki Altaj (mater. konf.) [History and modernity of Altai Republic (conference proceedings)]. Gorno-Altajsk, Komitet po delam arhivov Respubliki Altaj Publ., 20I2, pp. II-I4. (In Russ.) 